\title{
Meningkatkan Kualitas Pembelajaran Siswa melalui Eksplorasi Bentuk- Bentuk Geometri dengan Berbagai Media di Tk Fransisko Waigete
}

\author{
Selestina Lehang \\ Guru di TK Fransisko Waigete, Kab. Sikka, Nusa Tenggara Timur \\ Email: selestina.lehang@ gmail.com \\ DOI : 10.32672/jsa.v7i5.1529
}

\begin{abstract}
ABSTRAK
Tujuan yang ingin dicapai dalam penelitian ini adalah untuk meningkatkan kualitas pembelajaran siswa melalui eksplorasi bentuk-bentuk geometri di TK Fransisko Waigete. Penelitian dilaksanakan di TK tersebut pada bulan Agustus dan September 2019 dalam dua siklus. Instrumen penelitian menggunakan lembar hasil belajar dan lembar observasi. Lembar hasil belajar digunakan untuk mencatat data kuantitatif berupa hasil belajar siswa sebelum siklus dan sesudah siklus. Lembar observasi digunakan untuk mencatat data kualitatif berupa pengamatan tentang partisipasi siswa dalam kegiatan pembelajaran sebelum siklus dan sesudah siklus. Analisis data menggunakan teknik deskriptif analitik. Data kuantitatif dari lembar hasil belajar diolah menggunakan analisis persentase. Data kualitatif dari lembar observasi, diklasifikasikan berdasarkan aspek-aspek yang dijadikan fokus analisis. Data kuantitatif dan data kualitatif kemudian dikaitkan sebagai dasar untuk mendeskripsikan keberhasilan penerapan berbagai media pembelajaran, yang ditandai dengan meningkatnya hasil belajar bentuk-bentuk geometri dan perubahan partisipasi (tingkah laku siswa di kelas) yang menyertainya.Indikator kinerja dari data kuantitatif ditetapkan kriteria bahwa semakin meningkat perolehan hasil belajar bentuk-bentuk geometri para siswa pada kategori diatasnya menunjukkan kriteria peningkatan kualitas pembelajaran. Indikator kinerja dari data kualitatif ditetapkan bahwa peningkatan partisipasi siswa dan peningkatan sikap positif baik dari segi kualitas maupun kuantitasnya sebagai indikator peningkatan pembelajaran yang positif dari siklus ke siklus. Hasil penelitian menunjukkan bahwa hasil belajar siswa meningkat dari siklus ke siklus. Peningkatan hasil belajar siswa diikuti oleh peningkatan kriteria partisipasi siswa dari siklus ke siklus. Hal ini ditandai oleh peningkatan persentase hasil belajar siswa yang memperoleh kriteria baik (skor 4) dan sangat baik (skor 5), yaitu dari semula $0 \%$ (baik) dan 0\% (sangat baik) pada saat sebelum siklus, menjadi 24,39\% (baik) dan 39,02\% (baik) pada siklus I, dan meningkat menjadi $24,39 \%$ (baik) dan $75,60 \%$ (sangat baik) pada siklus II. Simpulan : Penerapan berbagai media pada pembelajaran bentuk-bentuk geometri dapat meningkatkan kualitas pembelajaran pada siswa TK Fransisko Waigete pada Tahun Pelajaran 2019-2020.
\end{abstract}

Kata Kunci : Media Pembelajaran, Pembelajaran, Bentuk-Bentuk Geometri.

\section{PENDAHULUAN}

Dalam konteks empiris, banyak siswa Taman Kanak-kanak (TK) yang kurang menguasai materi pembelajaran bentuk-bentuk Geometri. Para guru juga kesulitan dalam 
membelajarkan materi bentuk-bentuk Geometri, karena keterbatasan media pembelajaran, pengalaman mengajar, minimnya keaktifan siswa, dan lain-lain. Akibatnya, kualitas pembelajaran bentuk-bentuk Geometri tidak optimal.

Suydan dan Khusni (1999:3) menjelaskan, bahwa geometri merupakan bagian dari matematika yang mempelajari pola-pola visual, yang akan menghubungkan matematika dengan dunia nyata. Geometri juga dapat di pandang sebagai sistem matematika yang menyajikan fenomena yang bersifat abstrak (tidak nyata). Kalaupun objek geometri itu abstrak, akan tetapi mereka adalah sebuah kenyataan bahwa geometri sangat penting dan berperan dalam kehidupan. Geometri menjadi materi yang ingin diketahui secara mendasar dan fundamental untuk pengembangan matematika itu sendiri dan pengembangan kemampuan berfikir manusia secara logis. (Suydan dan Khusni (1999:3).

Selanjutnya Suydan dan Khusni (1999:3) menyatakan, bahwa salah satu tujuan diajarkanya Geometri di sekolah-sekolah adalah mengembangkan kemampuan berfikir logis, agar siswa menganalisis lebih jauh dunia tempat hidupnya serta memberikan sejak dini landasan berupa konsep-konsep dan peristilahan yang diperlukan pada pendidikan jenjang berikutnya (Suydan dan Khusni (1999:3). Sejalan dengan itu, Departemen Pendidikan Nasional memandang penting untuk memasukkan materi pelajaran geometri tidak hanya dimulai sejak Sekolah Dasar, melainkan dimasukkan sejak pendidikan Taman Kanak-kanak (Permendiknas No. 58 Tahun 2009 : 12).

Sampai saat ini pembelajaran bentuk-bentuk geometri di TK Fransisko Waigete masih belum menarik bagi para siswa. Data empiris dari observasi pendahuluan pada bulan Juli 2019 menunjukkan, bahwa dari jumlah 41 anak (siswa), ternyata perolehan skor hasil belajar Bentuk-bentuk Geometri yaitu : a) skor $1: 7$ anak; skor $2: 18$ anak; skor 3 : 16 anak; skor 4 : 0 anak; dan skor 5: 0 anak. Persentase perolehan skor tersebut masih jauh dari harapan. Sekalipun ada siswa yang mendapatkan skor 1 sebanyak 7 anak $(17,07)$, tetapi juga tidak ada siswa yang mendapatkan skor 4 apalagi skor 5. Sementara yang mendapatkan skor 2 sebanyak 43,90 \%: (18 anak), dan skor 3 sebanyak 39,02 \% (16 anak).

Demikian halnya perilaku anak dalam proses pembelajaran juga tidak optimal. Konsentrasi siswa dalam mengikuti pembelajaran, antusiasme, tanggung jawab, keaktifan mengajukan pertanyaan, keberanian menjawab pertanyaan dan keberanian menanggapinya, masih minim. Melihat kenyataan tersebut, penulis memandang perlu untuk dilakukan berbagai langkah guna meningkatkan kualitas pembelajaran bentukbentuk geometri, sehingga mendapatkan hasil belajar yang optimal. Adapun di antara langkah-langkah yang perlu dilakukan ialah dengan menerapkan berbagai media pembelajaran dalam proses pembelajaran bentuk-bentuk geometri.

\section{METODE PENELITIAN Desain Penelitian}

Penelitian ini merupakan penelitian tinda kan kelas, yaitu suatu bentuk penelitian yang bersifat reflektif yang melakukan beberapa tindakan tertentu agar dapat memperbaiki serta meningkatkan kualitas pembelajaran di kelas secara lebih profesional.

Sesuai dengan judul tersebut, maka yang menjadi subyek dalam penelitian tindakan kelas ini adalah siswa TK Fransisko Waigete pada Tahun Pelajaran 2019/2020 
yang berjumlah 41 anak. Penelitian tindakan kelas ini dilaksanakan pada bulan Agustus dan September 2019 dalam 2 (dua) siklus. Masing-masing siklus sekali pertemuan dengan waktu 150 menit.

\section{Prosedur Penelitian}

Dalam rangka meningkatkan kualitas pembelajaran bentuk-bentuk geometri pada siswa TK Fransisko, maka penelitian tindakan kelas ini dilakukan dalam 2 siklus, dengan alur penelitian sebagai berikut :

\section{Siklus I}

\section{Perencanaan}

Menyediakan perangkat penelitian, meliputi : (a) Rencana Kegiatan Harian (RKH) yang mencakup: indikator, kegiatan pembelajaran, alat/sumber belajar dan penilaian perkembangan anak; (2) Menyiapkan berbagai media pembelajaran, yaitu: media gambar diam/mati, media grafis, media model, dan media realita; (3) membuat lembar observasi siswa; (4) Membuat lembar hasil belajar siswa

\section{Pelaksanaan Tindakan}

Rencana pembelajaran yang telah dirancang pada tahap perencanaan, dilaksanaan sepenuhnya pada tahap pelaksanaan ini. Secara garis besar kegiatannya mencakup hal-hal sebagai berikut : (a) Membuka pembelajaran meliputi : berbaris, ikrar, salam dan doa, serta menghafal nama bentuk-bentuk geometri (lingkaran, segitiga, segiempat; (b) Kegiatan inti pembelajaran : menyampaikan materi bentuk-bentuk Geometri dengan berbagai media pembelajaran, yaitu: (1) Media gambar mati/diam: (2) Media grafis; (3) Media model; (4) Media realita; (c) Kegiatan penutup, meliputi : kegiatan membuat lembar hasil belajar siswa melalui soal formatif, dan doa penutup.

\section{Observasi}

Observasi dilakukan dari awal sampai akhir proses pembelajaran untuk mencatat partisipasi siswa, meliputi: konsentrasi siswa, antusiasme siswa, tanggungjawab siswa, keberanian siswa mengajukan pertanyaan, dan keberanian siswa menjawab pertanyaan.

\section{Refleksi}

Berdasarkan hasil observasi dan hasil belajar siswa, maka peneliti akan menetapkan : (1) Mana yang telah dicapai oleh siswa dalam memahami bentuk-bentuk geometri; (2) Mana yang belum dicapai oleh siswa dalam memahami bentuk-bentuk geometri; (3) Apa yang perlu diperbaiki dalam siklus berikutnya.

\section{Siklus II}

Perencanaan; yang meliputi (a) Rencana Kegiatan Harian (RKH) yang mencakup: indikator, kegiatan pembelajaran, alat/sumber belajar dan penilaian perkembangan anak; (b) Menyiapkan berbagai media pembelajaran, yaitu: media gambar diam/mati, media 


\section{Selestina Lehang}

grafis, media model, dan media realita; (c) Membuat lembar observasi siswa; (d)Membuat lembar hasil belajar siswa

Pelaksanaan Tindakan

Rencana pembelajaran yang telah dirancang pada tahap perencanaan, dilaksanaan sepenuhnya pada tahap pelaksanaan ini. Secara garis besar kegiatannya mencakup hal-hal sebagai berikut: (a) Membuka pembelajaran meliputi: berbaris, ikrar, salam dan doa, serta menghafal nama bentuk-bentuk geometri (lingkaran, segitiga, segiempat); (b) Kegiatan inti pembelajaran: menyampaikan materi bentuk-bentuk geometri dengan berbagai media pembelajaran; (c) Kegiatan penutup, meliputi : kegiatan membuat lembar hasil belajar siswa melalui soal formatif, dan doa penutup.

\section{Observasi}

Observasi dilakukan dari awal sampai akhir proses pembelajaran pada Siklus II untuk mencatat partisipasi siswa meliputi: konsentrasi siswa, antusiasme siswa, tanggungjawab siswa, keberanian siswa mengajukan pertanyaan, dan keberanian siswa menjawab pertanyaan.

\section{Refleksi}

Pada tahap ini peneliti segera menganalisis pelaksanaan penelitian setelah kegiatan pembelajaran berakhir sebagai bahan refleksi. Disamping itu, mencatat kekurangan dan kendala dalam pelaksanaan pembelajaran pada siklus II. Apabila masih ada kekurangan dan kendala maka akan dicarikan solusi untuk mengatasinya pada siklus berikutnya. Sedangkan apabila kualitas pembelajaran telah tercapai, maka pelaksanaan berhenti pada siklus II.

\section{Instrumen Penelitian}

\section{Lembar observasi.}

Lembar observasi digunakan untuk mengamati dan mencatat hasil pengamatan tentang partisipasi siswa di kelas dalam proses pembelajaran, meliputi: konsentrasi siswa, antusiasme siswa, tanggungjawab siswa, keberanian siswa menjawab pertanyaan, dan keberanian siswa mengajukan pertanyaan.

\section{Teknik Pengumpulan Data \\ Teknik observasi}

Teknik ini penulis gunakan untuk mengumpulkan data tentang partisipasi siswa di kelas, meliputi: konsentrasi siswa, antusiasme siswa, tanggungjawab siswa, keberanian siswa mengajukan pertanyaan, dan keberanian siswa menjawab pertanyaan.

\section{Teknik tes.}

Teknik ini digunakan untuk mengetahui hasil belajar siswa setelah proses pembelajaran. Pada setiap siklus guru memberikan tes formatif secara lisan untuk mengukur kemampuan siswa dalam penguasaan materi bentuk-bentuk geometri dengan berbagai media pembelajaran. 


\section{Teknik Wawancara}

Teknik ini penulis gunakan untuk mengumpulkan data kualitatif, khususnya tentang gambaran umum lokasi penelitian.

\section{Analisis Data}

Teknik yang digunakan untuk analisis data pada penelitian ini adalah teknik deskriptif analitik. Data kuantitatif yang diperoleh dari lembar hasil belajar diolah menggunakan analisis persentase. Data kualitatif yang diperoleh dari lembar observasi, diklasifikasikan berdasarkan aspek-aspek yang dijadikan fokus analisis.

Data kuantitatif dan data kualitatif kemudian dikaitkan sebagai dasar untuk mendeskripsikan keberhasilan penerapan berbagai media pembelajaran, yang ditandai dengan meningkatnya hasil belajar bentuk-bentuk geometri dan perubahan partisipasi (tingkah laku siswa di kelas) yang menyertainya.

\section{Indikator Kinerja}

Penelitian ini adalah penelitian tindakan kelas, artinya penelitian dengan berbasis pada kelas. Indikator kinerja dari data kuantitatif ditetapkan kriteria bahwa semakin meningkat perolehan hasil belajar bentuk-bentuk geometri para siswa pada kategori diatasnya menunjukkan kriteria peningkatan kualitas pembelajaran dalam penelitian tindakan kelas ini. Jadi seumpama pada siklus kategori sangat baik lebih besar persentasenya daripada siklus I, berarti terjadi peningkatan kualitas pembelajaran yang positif. Sebaliknya seumpama pada siklus II kategori sangat baik lebih kecil atau sama persentasenya dengan siklus I, berarti tidak terjadi peningkatan kualitas pembelajaran yang positif.Indikator kinerja dari data kualitatif ditetapkan bahwa peningkatan partisipasi responden (siswa) dan peningkatan sikap positif baik dari segi kualitas maupun kuantitasnya sebagai indikator peningkatan pembelajaran yang positif, dari siklus ke siklus. Jika terjadi sebaliknya maka sebagai indikasi kurang berhasil dalam perlakuan Penelitian Tindakan Kelas ini.

\section{HASIL PENELITIAN DAN PEMBAHASAN Deskripsi Pra Siklus}

Sebelum penelitian tindakan kelas ini penulis laksanakan, penulis sebagai guru menerapkan media pembelajaran bentuk-bentuk geometri kepada siswa TK Fransisko, hanya dengan media gambar diam/mati dan media grafis. Dengan menerapkan media gambar diam/mati dan media grafis, kualitas pembelajaran bentuk-bentuk Geometri pada siswa tidak optimal. Tes formatif secara lisan kepada 41 siswa sebelum siklus diperoleh skor hasil belajar siswa sebagaimana dalam tabel berikut ini. 
Selestina Lehang

Tabel 1. Data Hasil Belajar Siswa Sebelum Siklus

\begin{tabular}{|c|c|c|c|c|}
\hline No. & Kategori & Skor & Jml Siswa & Persentase \\
\hline 1 & Sangat baik & 5 & 0 & $0 / 41 \times 100 \%=$ \\
\hline 2 & Baik & 4 & 0 & $0 / 41 \times 100 \%=$ \\
\hline 3 & Cukup baik & 3 & 16 & $16 / 41 \times 100 \%=39,02 \%$ \\
\hline 4 & Kurang baik & 2 & 18 & $18 / 41 \times 100 \%=43,90 \%$ \\
\hline 5 & Tidak baik & 1 & 7 & $7 / 41 \times 100 \%=17.07 \%$ \\
\hline \multicolumn{3}{|c|}{ Jumlah } & 41 & $100 \%$ \\
\hline
\end{tabular}

Persentase perolehan skor tersebut masih jauh dari harapan. Masih ada siswa yang mendapatkan skor 1, dan juga tidak ada siswa yang mendapatkan skor 4 dan 5. Sementara siswa yang mendapatkan skor 2 sebanyak 43,90 \%: (18 anak), sedangkan 39,02 \% (16 anak) mendapatkan skor 3 (cukup baik). Sedangkan 7 orang siswa mendapatkan skor 1 (tidak baik) dengan persentase $17,07 \%$.

Demikian halnya dengan partisipasi siswa (perilaku anak di kelas) dalam proses pembelajaran juga tidak optimal. Observasi pendahuluan dengan aspek observasi meliputi : konsentrasi siswa, antusiasme, tanggung jawab, keaktifan mengajukan pertanyaan dan keberanian siswa menjawab pertanyaan, diperoleh skor partisipasi siswa (perilaku anak di kelas) sebagaimana dalam tabel 2 berikut ini.

Tabel 2. Data Partisipasi Siswa Pra Siklus

\begin{tabular}{|c|l|c|c|cr|}
\hline No. & Kategori & Skor & Iml Siswa & \multicolumn{2}{|c|}{ Persentase } \\
\hline 1 & Sangat baik & 5 & 0 & $0 / 41 \times 100 \%=$ & $0 \%$ \\
\hline 2 & Baik & 4 & 0 & $0 / 41 \times 100 \%=$ & $0 \%$ \\
\hline 3 & Cukup baik & 3 & 31 & $31 / 41 \times 100 \%=75,60 \%$ \\
\hline 4 & Kurang baik & 2 & 10 & $10 / 41 \times 100 \%=24,39 \%$ \\
\hline 5 & Tidak baik & 1 & 0 & $0 / 41 \times 100 \%=$ & $0 \%$ \\
\hline \multicolumn{2}{|l|}{ Jumlah } & & 41 & & $100 \%$ \\
\hline
\end{tabular}

Sumber data : Lembar Observasi Siswa sebelum Siklus 
Serambi Akademica

Jurnal Pendidikan, Sains, dan Humaniora
Vol. 7, No. 5,

Oktober 2019
pISSN 2337-8085

eISSN 2657- 0998

\section{Deskripsi Hasil Siklus I}

Berdasarkan penelitian yang sudah dilakukan, data peningkatan hasil belajar siswa dapat digambarkan pada Tabel 3 berikut.

Tabel 3. Data Hasil Belajar Siswa Siklus I

\begin{tabular}{|c|c|c|c|c|c|}
\hline No. & Kategori & Skor & Jml Siswa & \multicolumn{2}{|l|}{ Persentase } \\
\hline 1 & Sangat baik & 5 & 16 & \multicolumn{2}{|c|}{$16 / 41 \times 100 \%=39,02 \%$} \\
\hline 2 & Baik & 4 & 10 & \multicolumn{2}{|c|}{$10 / 41 \times 100 \%=24,39 \%$} \\
\hline 3 & Cukup baik & 3 & 10 & \multicolumn{2}{|c|}{$8 / 41 \times 100 \%=24,39 \%$} \\
\hline 4 & Kurang baik & 2 & 5 & $5 / 41 \times 100 \%=$ & $12,19 \%$ \\
\hline 5 & Tidak baik & 1 & 0 & $0 / 41 \times 100 \%=$ & $0 \%$ \\
\hline \multicolumn{3}{|c|}{ Jumlah } & 41 & & $100 \%$ \\
\hline
\end{tabular}

Sumber data : Lembar Hasil Belajar Siswa Siklus I

Berdasarkan data pada Tabel 3 tersebut, dapat diketahui adanya dampak positif dari tindakan pada Siklus I dengan menerapkan berbagai media pada pembelajaran bentuk-bentuk geometri. Pada sebelum siklus, tidak ada seorang siswa pun yang mendapat skor 4 dan 5. Setelah siklus I ternyata naik sangat tajam, siswa yang mendapat skor 4 dan 5 mencapai 24,39\% (10 anak) dan 39,02\% (16 anak).

Peningkatan hasil belajar tersebut menunjukkan bahwa semakin meningkat perolehan hasil belajar siswa pada kategori diatasnya menunjukkan kriteria peningkatan kualitas pembelajaran dalam penelitian tindakan kelas ini. Peningkatan hasil belajar tersebut, juga ikuti oleh peningkatan partisipasi siswa (perilaku anak di kelas). Dari lembar observasi tentang partisipasi siswa di kelas diperoleh data dalam Tabel 4 berikut ini.

Tabel 4. Data Partisipasi Siswa Siklus I

\begin{tabular}{|c|c|c|c|c|c|}
\hline No. & Kategori & Skor & Jml Siswa & \multicolumn{2}{|l|}{ Persentase } \\
\hline 1 & Sangat baik & 5 & 26 & \multicolumn{2}{|c|}{$6 / 41 \times 100 \%=63,41 \%$} \\
\hline 2 & Baik & 4 & 10 & \multicolumn{2}{|c|}{$6 / 41 \times 100 \%=24,39 \%$} \\
\hline 3 & Cukup baik & 3 & 5 & \multicolumn{2}{|c|}{$9 / 41 \times 100 \%=12,19 \%$} \\
\hline 4 & Kurang baik & 2 & 0 & $0 / 41 \times 100 \%=$ & $0 \%$ \\
\hline 5 & Tidak baik & 1 & 0 & $0 / 41 \times 100 \%=$ & $0 \%$ \\
\hline \multicolumn{3}{|c|}{ Jumlah } & 41 & & $100 \%$ \\
\hline
\end{tabular}


Selestina Lehang

Data partisipasi siswa dalam Tabel 4 tersebut menunjukkan bahwa ada peningkatan aktivitas belajar siswa. Peningkatan itu ditunjukkan dengan siswa yang mendapat skor 5 sebanyak 26 orang $(63,41 \%)$, yang mendapat skor 4 sebanyak 10 siswa $(24,39 \%)$ dan yang mendapatkan skor 3 sebanyak 12,19\%).

\section{Deskripsi Hasil Siklus II}

Setelah dilakukan tindakan pada Siklus II, dari lembar hasil belajar siswa diperoleh data pada Tabel 5 berikut ini.

Tabel 5. Data Hasil Belajar Siswa Siklus II

\begin{tabular}{|c|c|c|c|c|c|}
\hline No. & Kategori & Skor & Jml Siswa & \multicolumn{2}{|l|}{ Persentase } \\
\hline 1 & Sangat baik & 5 & 31 & \multicolumn{2}{|c|}{$31 / 41 \times 100 \%=75,60 \%$} \\
\hline 2 & Baik & 4 & 10 & \multicolumn{2}{|c|}{$10 / 41 \times 100 \%=24,39 \%$} \\
\hline 3 & Cukup baik & 3 & 0 & $0 / 41 \times 100 \%=$ & $0 \%$ \\
\hline 4 & Kurang baik & 2 & 0 & $0 / 41 \times 100 \%=$ & $0 \%$ \\
\hline 5 & Tidak baik & 1 & 0 & $0 / 41 \times 100 \%=$ & $0 \%$ \\
\hline \multicolumn{3}{|c|}{ Jumlah } & 41 & & $00 \%$ \\
\hline
\end{tabular}

Berdasarkan data pada Tabel 5 tersebut, dapat diketahui adanya peningkatan hasil belajar yang signifikan jika dibandingkan dengan siklus I. Diketahui terjadi peningkatan hasil belajar siswa, yang mana sebanyak 31 siswa mendapatkan skor $5(75,60 \%)$ dan sebanyak 10 siswa mendapatkan skor $4(24,39 \%)$.

Signifikansi peningkatan hasil belajar tersebut, ternyata didukung oleh peningkatan partisipasi siswa (perilaku anak di kelas) pada siklus II. Dari lembar observasi siswa pada siklus II diperoleh data pada Tabel 6 berikut ini.

Tabel 6. Data Partisipasi Siswa Siklus II

\begin{tabular}{|c|c|c|c|c|c|}
\hline No. & Kategori & Skor & Jml Siswa & \multicolumn{2}{|l|}{ Persentase } \\
\hline 1 & Sangat baik & 5 & 31 & \multicolumn{2}{|c|}{$31 / 41 \times 100 \%=75,60 \%$} \\
\hline 2 & Baik & 4 & 10 & \multicolumn{2}{|c|}{$10 / 41 \times 100 \%=24,39 \%$} \\
\hline 3 & Cukup baik & 3 & 0 & $0 / 41 \times 100 \%=$ & $0 \%$ \\
\hline 4 & Kurang baik & 2 & 0 & $0 / 41 \times 100 \%=$ & $0 \%$ \\
\hline 5 & Tidak baik & 1 & 0 & $0 / 41 \times 100 \%=$ & $0 \%$ \\
\hline \multicolumn{3}{|c|}{ Jumlah } & 41 & & $00 \%$ \\
\hline
\end{tabular}


Hasil penelitian tindakan kelas dalam rangka meningkatkan kualitas pembelajaran pada siswa TK Fransisko Waigete Tahun Pelajaran 2019-2020 melalui eksplorasi bentukbentuk geometri dengan berbagai media pembelajaran, dapatlah dilakukan pembahasan sebagai berikut :

Pertama, secara umum semakin meningkatnya hasil belajar siswa pada kategori diatasnya dari siklus ke siklus menunjukkan kriteria peningkatan kualitas pembelajaran dalam penelitian tindakan kelas ini. Dan peningkatan partisipasi siswa dari siklus ke siklus menunjukkan peningkatan sikap positif baik dari segi kualitas maupun kuantitasnya sebagai indikator peningkatan pembelajaran yang positif.

Kedua, peningkatan kualitas pembelajaran bentuk-bentuk geometri, yang dalam hal ini ditandai oleh adanya peningkatan hasil belajar siswa dan partisipasi siswa di kelas; mulai tampak nyata dari sebelum siklus ke siklus I, dan lebih nyata lagi peningkatan kualitas pembelajaran dari siklus I ke siklus Di mana pada siklus II perolehan hasil belajar siswa semuanya mencapai kriteria baik dan sangat baik, dan diikuti oleh peningkatan partisipasi siswa yang juga semuanya mencapai kriteria baik dan sangat baik.

Ketiga, kualitas pembelajaran sebagai suatu kegiatan siswa dalam upaya memperoleh pengetahuan, ketrampilan dan nilai-nilai positif dengan memanfaatkan berbagai sumber untuk belajar secara efektif. Dengan kata lain, kualitas pembelajaran adalah proses pembelajaran yang efektif (Rudi Susilana dan Cepi Riyana, 2007 : 1). Sementara itu Badru Zaman, dkk. menegasakan bahwa salah satu fungsi media pembelajaran adalah untuk meningkatkan kualitas proses pembelajaran (Badru Zaman, dkk., 2008 : 4.12). Maka dengan menerapkan berbagai media pembelajaran, dalam hal ini menerapkan media gambar diam/mati, media grafis, media model, dan 4 media realita dalam pembelajaran bentuk-bentuk geometri; ternyata benar-benar terbukti. Artinya, berbagai media pembelajaran sebagai salah satu sumber belajar efektif, benar-benar berfungsi meningkatkan kualitas pembelajaran.

Hal itu juga sesuai dengan pendapat Suydan dan Khusni, bahwa objek geometri itu abstrak, akan tetapi mereka adalah sebuah kenyataan bahwa geometri sebagai suatu aspek matematika yang sangat penting dan berperan dalam kehidupan. Geometri menjadi materi yang ingin diketahui secara mendasar dan fundamental untuk pengembangan matematika itu sendiri dan pengembangan kemampuan berfikir manusia secara logis. Adapun salah satu tujuan diajarkanya geomteri di sekolah adalah mengembangakan kemampuan berfikir logis. Tujuan dasar untuk memberi kesempatan siswa menganalisis lebih jauh dunia tempat hidupnya serta memberikan sejak dini landasan berupa konsep-konsep dan peristilahan yang diperlukan pada pendidikan jenjang berikutnya (Suydan dan Khusni (1999:3).

Dengan demikian dapatlah disimpulkan, bahwa eksplorasi bentuk-bentuk geometri dengan barbagai media dapat meningkatkan kualitas pembelajaran bentuk-bentuk geometri pada siswa TK Fransisko Waigete. 
Selestina Lehang

PENUTUP

Simpulan

Penelitian tindakan kelas ini menyimpulkan bahwa penerapan berbagai media pembelajaran pada pembelajaran bentuk-bentuk geometri dapat meningkatkan kualitas pembelajaran pada siswa TK Fransisko Waigete. Hal ini ditandai oleh peningkatan persentase hasil belajar siswa yang memperoleh kriteria baik (skor 4) dan sangat baik (skor 5), yaitu dari semula $0 \%$ (baik) dan $0 \%$ (sangat baik) pada saat sebelum siklus, menjadi $24,39 \%$ (baik) dan 39,02\% (baik) pada siklus I, dan meningkat menjadi $24,39 \%$ (baik) dan $75,60 \%$ (sangat baik) pada siklus II.

\section{DAFTAR PUSTAKA}

Amirul Mukminin. 2011. Evaluasi Pembelajaran PAUD : Universitas Negeri Semarang. Badru Zaman, Asep Hery Hernawan, Cucu Eliyawati. 2008. Media dan Sumber Belajar $T K$. Jakarta : Universitas Terbuka

Direktorat Pendidikan TK dan SD. 2005. Kurikulum 2004 Standar Kompetensi Taman Kanak-kanak dan Raudhatul Athfal. Jakarta : Dirjen Manajemen Dikdasmen Departemen Pendidikan Nasional.

Poerwadarminta, W.J.S. 1986. Kamus Umum Bahasa Indonesia. Jakarta : PN Balai Pustaka.

Rudi Susilana, M.Si dan Cepi Riyana, M.Pd. 2007. Media Pembelajaran, Hakikat, Pengembangan, Pemanfaatan, dan Penilaian, Seri Pembelajaran Efektif. Jakarta : Raja Grafindo Persada.

Mansur, S. 2018. Pengaruh Pendekatan Jelajah Alam Sekitar (JAS) Terhadap Hasil Belajar Siswa Pada Materi Klasifikasi Mahluk Hidup di SMPK Binawirawan Maumere. Uhamka. Bioeduscience. 2 (1): 74-80. DOI: 10.29405/j.bes/7480121314

Mansur, S dan Loli. M.P.P. 2019. Upaya Meningkatkan Hasil Belajar Siswa Kelas VII dengan Model Guide Note Taking di SMP San Karlos Habi. Uin Raden Intan Lampung. BIOSFER: Jurnal Tadris Biologi. 10 (1): 21-28. DOI: https://doi.org/10.24042/biosfer.v10i1.3990

Soewardi. 1984. Melukis Bentuk Geometri. Jakarta : PT Gramedia.

Suharsimi Arikunto, Prof. Dr. 2006. Prosedur Penelitian Suatu Pendekatan Praktek. Jakarta : Rineka Cipta.

Suydan_dan Khusni (1999:3). http://wikipedia.org/wiki/geometri, diakses 26 Agustus 2019, tersedia dalam www.google.com

Wina, Sanjaya, 2008. Perencanaan dan Desain Sistem Pembelajaran. Jakarta. Kencana Prenada Media Group. 